Keio Journal of Medicine Vol. 9, No. 3, Se pte mber, 1960

\title{
CONCEPT OF "FOCUSED REACTION" WITH SPECIAL REFERENCE TO TONSILLAR LESION
}

\author{
YASUNOBU SUZUKI \\ Department of Oto-Rhino-Laryngology \\ MASAHARU TSUCHIYA \\ Department of Internal Medicine \\ School of Medicine, Keio University \\ (Received for publication June 22, 1960)
}

For the past several years we have studied the effect of excessive stimuli (irritation) to the autonomic nervous system upon the distant organs, particularly concerning the changes of the circulatory system. In order to describe the phenomena observed under these conditions we think it is appropriate to coin a new term of "Focused Reaction." In this term, "focused" which is derived from the Latin word "focus" is used in the same sense as in optics or photography, namely refering to burning point of a lens. The etymology of the word "focal" used currently in medicine as in "focal infection," is from the same Latin word, but here it denotes a fireplace or hearth. For instance, the lesion of the tonsil is the "focus" from which a noxious influence originates to exert its influence upon distant organs such as the heart, kidney and so on, thus establishing the "focal infection."

When a part of the body is affected by the noxious influence of the irritation from the site of infection, as well as by some physical, chemical or mental stresses, a nociceptive reflex takes place in various organs of the body, resulting in disturbances of capillary system and pathological changes within the organs. We think, that the site where such changes occur can be regarded as the focus and the entire process can be called "Focused Reaction." The organs affected vary depending upon the site to which the stimuli are given. For example, the relation between the skin and the internal organs correspond to Head's zone and Onodera's point of pressure. In the case of the tonsil, when the skin of the neck is exposed to a stimulus such as cold draft, a nociceptive reflex takes place in the tonsil via the autonomic nervous system resulting in circulatory disturbance with enormous dilatation of capillaries and edema in the perivascular tissue as well as hemorrhage, degeneration and necrosis.

The pattern and extent of the reaction proved by Reilly's experiment is. 
variable depending upon the environmental condition and disposition of the individual, but, even if not serious, when the reaction is focused upon the tonsil, it provides for a ground for activation of the bacteria virus which might happen to be present there, causing development of a inflammatory process at the site, i.e., tonsillitis. It is not an uncommon experience to find streptococci or diphtheria bacilli from the tonsillar lacunae of adults or school children, who are enjoying good health. This fact cannot be explained on the basis of immunity alone, since not all of them are proven to possess the antibody.

On the other hand, the concept of focused reaction seems to us to offer an explanation in these cases. We think it is reasonable to postulate that when these carriers are exposed to cold, the irritation given to them on the skin, especially on the skin of the neck, is focused upon the pharyngeal region, particulary the tonsils where autonomic nerves are abundantly present, causing disturbances of capillary system, and bacterial activation as described above, giving rise to a fullblown picture of tonsillits or diphtheria. Thus, it seems possible that certain percentage of cases of these diseases are the result of Focused Reaction. Once tonsillitis has been established, bacterial growth, production and absorption of toxin takes place within the tonsil itself. At the same time, the vascular changes as mentioned above occur within and around the tonsillar tissue, and tonsillar hypertrophy results. These changes causes excessive stimulation of the autonomic nervous system within and around the tonsils. These stimuli are transmitted to various organs, particularly the heart and the kidney. Changes in other organs which are ordinarily attributed to focal infection may be found as well.

In our opinion, these changes are regarded as the result of Focused Reaction "focused" upon these organs. The changes in the heart are in its early stage, so mild as to be detectable only on electrocardiorgram, and it is only after irritation has been repeated and chronic process has been established that they become manifest histologically. The changes in the kidney and the other organs are induced by the same mechanism.

It is necessary to bear this mechanism in mind when tonsillectomy is to be done for treating the diseases currently attributed to focal infection, such as nephritis, idiopathic renal hemorrhage, rheumatic arthritis etc. Sometimes, it is observed that these diseases are aggravated by tonsillectomy. This phenomenon can easily be explained by assuming that the surgical intervention has worked as an additional stress to these organs. At the site repeatedly involved in Focused Reaction, the above mentioned circulatory disturbance takes place which favors for the growth of bacteria and inflammation ensues. Excessive stimuli 
originating from the tonsil may sometimes be focused upon the skin, causing various changes there. Some of the skin diseases, such as Erythema exsudativum multiforme or Erythema ncdosum which are sometimes successfully treated by tonsillectomy, may be the result of Focused Reaction. Allergic theory cannotbe denied either in the pathogenesis of these conditions.

The fact that the skin is involved preferentially in certain types of antigenantibody reaction whereas the antibcdy is present uniformly in the entire tissue fluid induces us to postulate that the skin has been, in one way or another, conditioned in favor of such pathological processes, and the Focused Reaction plays a rôle in the process of conditioning. Rheumatic diseases which are also sometimes ameliorated by tosillectomy, may be caused by the same mechanism.

The transmission of irritation is not uni-directional, but can be schematically presented as follows:

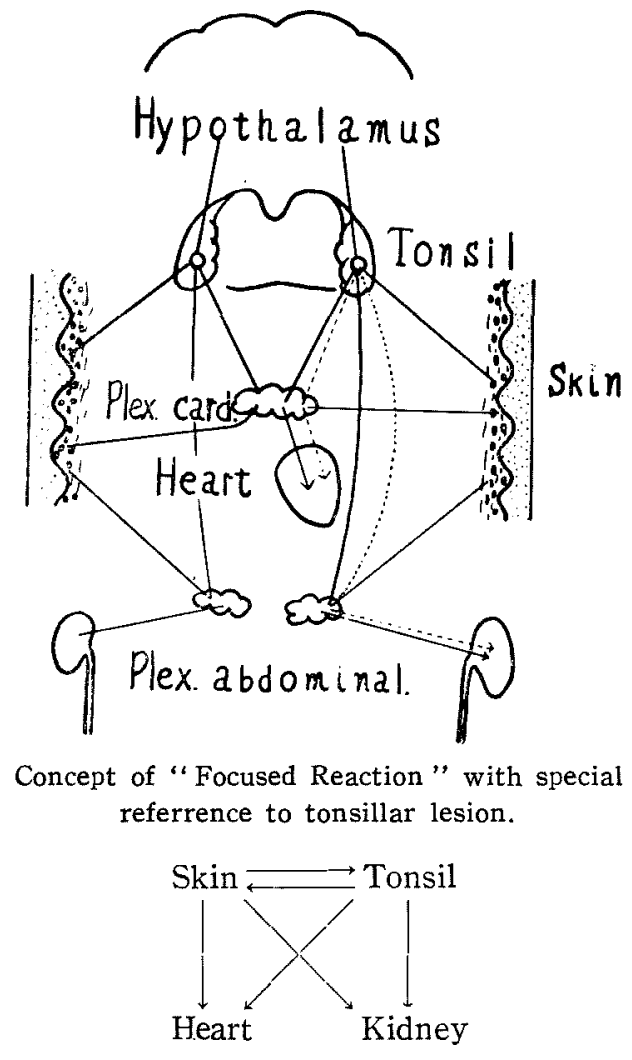

The target of the arrow $(\rightleftarrows$ ) is the focus in our difinition.

Stimuli may sometimes be transmitted to the focused organ via the brain: (especially the hypothalamus). These stimuli may, in the end, establish a. 
" circulus vitiosus."

In the foregoing statement, we paid most of our attention to the tonsil, but the same notion can be made in regard to the paranasal sinuses, teeth, as well as to relation between the skin and the kidney or heart. "Training the skin" as a measure of health keeping seems to find its justification in our concept of Focused Reaction. When the tonsil is already a site of bacterial growth, removal of the organ will check establishment of Focused Reaction, and prevent serious inflammation from occuring. Here is one of the basis for tonsillectomy. In chronic tonsillitis, milder stimuli are repeatedly emanating from the tonsil, exerting a noxious influence upon other organs. Tonsillectomy is indicated in these cases as well. In the case of nephritis, irritation not only from the tonsil, but from other sites of the body, the skin for example, should be checked as well. Therefore it should be condemned to do tonsillectomy on the nephritic in the poorly heated room of the clinic. The same precautions as the internist would give to these patients should be observed. These precautions would obviate agravation of symptoms which is sometimes encountered after tonsillectomy. It should be borne in mind that stimuli from the tonsil and from the skin act upon the focused organ synergistically.

In conclusion, we would like to emphasize the difference between the concept of focal infection which is currently in use and that of Focused Reaction as we have proposed in this paper.

\section{Résumé}

L'auteur a proposé un nouveau terme "Focused Reaction" pour exprimer la lésion observée dans l'infection focale. La lésion provoquée par l'infection focale est nonspécifique et n'est pas complètement expliquée par la théorie bactériologique ou allergique. Cette lésion basée à l'altération du système capillaire peut être provoquée par le réflexe nociceptif. Si ces réflexes déclanchés par de divers points du corps se superposent à une organe, la lésion de cette organe devient très grave. Considérant que le système neuro-végétatif joue un rôle important et principal dans la pathogénèse de l'infection focale, l'auteur a discuté de "Focused Reaction," en parlant de la relation intime entre l'amygdale et la peau, le rein ou le coeur.

In closing, we wish to express our thanks to Prof. T. Nishihata, chief of Department of Oto-Rhino-Laryngology, for his invaluable advice and en. courgement. And we are greatly indebted to Dr. M. Yasuda for his invaluable help in preparing the English manuscript of this paper.

This article is released on Feb. 28 in 1960 at 360nd Session of Oto-Rhino. Laryngology in Kanto District. 


\section{REFERENCES}

1. Fukazawa, H.: Prevention of Death due to Shock which may be elicited by Irritation of The palate in Guinea Pigs. Otolaryngology (Tokyo), 30: 169-176, 1958. (in Japanese and English Abstract)

2. Iida, M.: The Cause of Simulated Shock and Death due to Shock by Irritation of the Palate in Guinea Pigs. Otolaryngology (Tokyo), 30: 158-167, 1958. (in Japanese with English Abstract)

3. Igarashi, A: Histologic Changes in the Kidneys of Guinea Pigs after Injection of Hemolytic Streptococci into the Jugular Sacs. (Study of Reilly's Phenomenon) Journ. of the Oto-Rhino-Laryngological Society of Japan. 63: 941-949, 1960 . (in Japanese with English Abstract)

4. Inoue, T.: Changes produced in the Superior Cervical and Caeliac Sympathetic Ganglia by Irritation of the Lip in Guinea Pigs. Journ. of Oto-Rhino-Laryngological Society of Japan. 63: 995-1007, 1960. (in Japanese with English Abstract)

5. Ohno, F.: Studies on the Peripheral Nerv Route reaching the Lip of the Guinea Pig, and Distribution of Nerves, especially of the Autonomic Nerves in the Lip. Journ. of the Oto-Rhino-Laryngological Society of Japan. 63:56-66, 1960. (in Japanese with English Abstract)

6. Reilly, J., Compagnon, A., Laporte, A., et Du Buit, H.: Le Rôle du Système Nerveux en Pathologie Rénale. Masson et Cie, Paris, 1942.

7. Sakai, T.: Clinical Study on the Tonsillar Focal Infection (Chiefly on Renal Function by Clearance-Test) Journ. of the Oto-Rhino-Laryngological Society of Japan. 62: 2127-2185, 1959. (in Japanese with English Abstract)

8. Suzuki, K.: An Experimental Study on the Influence of Irritation of the Suborbital Nerve on various Remote Organs, especially on the Lung, and Blocking of the In. fluence in the Guinea Pig. Journ. of the Oto-Rhino-Laryngological Society of Japan, 60: 1181-1188, 1960. (in Japanes with English Abstract)

9. Suzuki, Y., Fukazawa, H. and Iida, M.: Studie on Experimental Shock and its Prevention in Guinea Pigs being applied Stimulation to the Palate. Keio J. Med. 7 (Centenary Number) : 39-57, 1958.

10. Suzuki, Y. and Nagase, K.: Pathohistological Pictures, Innervation and Clinical Considerations of Human Palatine Tonsils. Keio J. Med., 7 (Centenary Number) : 75-87, 1958.

11. Suzuki, Y., Kitsuta, T., Takasaki, A. and Suzuki, K.: An acute Pulmonary Edema provoked by Local Anesthesia during Sinus Operation. Otolaryngolo. (Tokyo), 30 : 800-801, 1958. (in Japanese with English Abstract)

12. Suzuki, Y., Yamaguchi, E., lida, M., Miyabe, I., Tsuchiya, M. and Ogawa, M.: Four Cases of Idiopathic Renal Hemorrhage successfuley treated with Tonsillectomy and Artificial Hibernation Therapy. Keio J. Med. 9: 131-142, 1960. (in English with French Abstract); Otolaryngology (Tokyo), 30:5-10, 1958. (in Japanese with English Abstract)

13. Suzuki, Y. et Kunishige, N.: Tonsillite et Néphrite. Revue de Laryng. Oto-Rhinol. (Bordeaux). 80 an. Nr. 6. 1959.

14. Suzuki, Y. and Tsuchiya, M.: Focal infection and Reilly's Phenomenon. Bull. méd. Franco-Japonais., 3: 11-16, 1957. (in Japanese)

15. Suzuki, Y. and Fukazawa, H.: Operation in the Field of Otolaryngology and Shock. Otolaryngology (Tokyo), 30: 153-158, 1958. (in Japanese with English Abstract)

16. Suzuki, Y., Yamaguchi, E., Iida, M., Igarashi, M., Suzuki, K. and Inoue, T.: Studies 
on Electrocardiograms taken befor and after Drainage of Peritosillar Abcess. Otolaryngology (Tokyo), 30:617-622, 1958. (in Japanese with English Abstract)

17. Takasaki, A.: A Study of Changes on the Lip due to Irritation and Amputation of the Infraorbital Nerve in Guinea Pig. Journ. of the Oto-Rhino-Laryngological Society of Japan. 63: 1250-1258, 1960. (in Japanese with English Abstract)

18. Tamagawa, K.: Electron Microscopic Studies on the Superior Cervical Ganglion of Guinea Pigs in the Normal and Experimental Reilly's Phaenomenon. Journ. of the Oto-Rhino-Laryngological Society of Japan. 63: 979-994, 1960. (in Japanese with English Abstract)

19. Yamaguchi, Y.: Reilly's Phenomenon. Saishinigaku. 10: 158, 1955. (in Japanese)

20. Yamaguchi, Y., Tsuchiya, M., Akiba, T., Kobayashi, K., Shiraishi, K. and Nozaki, H.: Experimental Studies on the Pathological Changes in the Several Organs due to Irritation of the Autonomic Nervous System. Keio J. Med. 9: 91-99, 1960. 